Correction

\title{
Correction: Bouvet F., et al., Debt Contagion in Europe: A Panel-Vector Autoregressive (VAR) Analysis. Soc. Sci. 2013, 2, 318-340
}

\section{Martin J. Bull}

Editor-in-Chief of Social Sciences, University of Salford, Crescent House, The Crescent, Salford, Manchester, M5 4WT, UK; E-Mail: m.j.bull@salford.ac.uk

Received: 27 March 2014 / Published: 27 March 2014

It has come to our attention that due to an error in producing the PDF version of the paper [1], doi:10.3390/socsci2040318, website: http://www.mdpi.com/2076-0760/2/4/318, some of the figures are displayed incorrectly.

The correct PDF version is available at http://www.mdpi.com/2076-0760/3/2/193/s1.

\section{References}

1. Bouvet, Florence, Ryan Brady, and Sharmila King. "Debt Contagion in Europe: A Panel-Vector Autoregressive (VAR) Analysis.” Social Sciences 2, no. 4 (2013): 318-40.

(C) 2014 by the author; licensee MDPI, Basel, Switzerland. This article is an open access article distributed under the terms and conditions of the Creative Commons Attribution license (http://creativecommons.org/licenses/by/3.0/). 